\title{
A conceptual, distributed snow redistribution model
}

\author{
S. Frey and H. Holzmann \\ Institute of Water Management, Hydrology and Hydraulic Engineering, University of Natural Resources and Life Sciences, \\ Vienna, Austria
}

Correspondence to: S. Frey (simon.frey@boku.ac.at)

Received: 10 December 2014 - Published in Hydrol. Earth Syst. Sci. Discuss.: 14 January 2015

Revised: 26 October 2015 - Accepted: 4 November 2015 - Published: 12 November 2015

\begin{abstract}
When applying conceptual hydrological models using a temperature index approach for snowmelt to high alpine areas often accumulation of snow during several years can be observed. Some of the reasons why these "snow towers" do not exist in nature are vertical and lateral transport processes. While snow transport models have been developed using grid cell sizes of tens to hundreds of square metres and have been applied in several catchments, no model exists using coarser cell sizes of $1 \mathrm{~km}^{2}$, which is a common resolution for meso- and large-scale hydrologic modelling (hundreds to thousands of square kilometres). In this paper we present an approach that uses only gravity and snow density as a proxy for the age of the snow cover and land-use information to redistribute snow in alpine basins. The results are based on the hydrological modelling of the Austrian Inn Basin in Tyrol, Austria, more specifically the Ötztaler Ache catchment, but the findings hold for other tributaries of the river Inn. This transport model is implemented in the distributed rainfall-runoff model COSERO (Continuous Semidistributed Runoff). The results of both model concepts with and without consideration of lateral snow redistribution are compared against observed discharge and snow-covered areas derived from MODIS satellite images. By means of the snow redistribution concept, snow accumulation over several years can be prevented and the snow depletion curve compared with MODIS (Moderate Resolution Imaging Spectroradiometer) data could be improved, too. In a 7-year period the standard model would lead to snow accumulation of approximately $2900 \mathrm{~mm}$ SWE (snow water equivalent) in high elevated regions whereas the updated version of the model does not show accumulation and does also predict discharge with more accuracy leading to a Kling-Gupta efficiency of 0.93 instead of 0.9. A further improvement can be shown in the comparison of MODIS snow cover data and the cal-
\end{abstract}

culated depletion curve, where the redistribution model increased the efficiency $\left(R^{2}\right)$ from 0.70 to 0.78 (calibration) and from 0.66 to 0.74 (validation).

\section{Introduction}

Conceptual models are widely used in hydrology. Examples are the HBV model (Bergström, 1976), PDM (Probability Distribution Model; Moore, 2007), GSM-SOCONT (Glacier and SnowMelt SOil CONTribution; Schaefli et al., 2005) and VIC (Variable Infiltration Capacity; Wood et al., 1992) just to name a few. Many of these conceptual models use a temperature index approach to model snowmelt and snow accumulation and even in some physically based models as e.g. versions of the SHE model (European Hydrological System; Bøggild et al., 1999) this method can be found. This approach has the advantage of being quite simple since it uses only temperature as input to determine whether precipitation occurs in the form of snow or rain and whether snow can be melted or not. A typical example of a temperature index method for snow modelling is the degree-day approach (see for example Hock, 2003). A disadvantage is that snow accumulates as long as the air temperature does not rise above a certain threshold (often $0^{\circ} \mathrm{C}$ ) regardless of any other processes that may lead to snowmelt like radiation or turbulent fluxes of latent energy. In high mountainous areas this may be the case for most days in the year leading to an intensive computational accumulation of snow in these areas. In the modellers terminology these artefacts are often called "snow towers". In nature, however, these accumulations are barley existent. 
The reasons for that are either wind or gravitationally induced lateral snow distribution processes (Elder et al., 1991; Winstral et al., 2002). Resulting snow depths are not uniformly distributed in space but vary within large ranges (Helfricht et al., 2014). When changing the focus from micro (e.g. several square metres) to meso-scales (e.g. one to several square kilometres), variations become less (Melvold and Skaugen, 2013). The intention of the applied snow redistribution concept was (i) to prevent the artefacts of "snow towers" and (ii) to develop a concept which considers gravity driven lateral snow transport with reasonable and plausible process depiction.

\subsection{Theoretical background of snow cover variations}

During the accumulation period, according to Liston (2004), primarily three mechanisms are responsible for these variations: (i) snow-canopy interactions in forest covered regions, (ii) wind-induced snow redistribution and (iii) orographic influences on snow fall. These mechanisms influence snow cover patterns on scales ranging from the micro to the macro scale. Spatial snow cover variability beneath canopies is mainly affected by different tree species (deciduous vs. coniferous trees) influencing leaf area index, height and density of the canopy and gap sizes (Garvelmann et al., 2013; Liston, 2004; Pomeroy et al., 2002).

Besides the impact of vegetation, wind is the most dominant factor influencing snow patterns in alpine terrain. Snow is transported from exposed ridges to the lee side of these ridges, valleys and vegetation-covered areas (Essery et al., 1999; Liston and Sturm, 1998; Rutter et al., 2009; Winstral et al., 2002). One has to be aware that besides of the physical transport of solid snow wind also stimulates sublimation processes (Liston and Sturm, 1998; Strasser et al., 2008). Wind influences snow depth distributions on the scale of hundreds to $1000 \mathrm{~m}^{2}$ (Dadic et al., 2010a).

The third mechanism (orographic effect) influences snow patterns on a larger scale of one to several kilometres (e.g. Barros and Lettenmaier, 1994). Non-uniform snow distributions are caused by interactions of the atmosphere (air pressure, humidity, atmospheric stability) with topography (Liston, 2004).

In addition to these processes, avalanches play a role in snow redistribution (Lehning and Fierz, 2008; Lehning et al., 2002; Sovilla et al., 2010). In steep terrain, avalanches depend mainly on the slope angle and are capable of transporting large snow masses over distances of tens to hundreds of metres (Dadic et al., 2010b; Sovilla et al., 2010).

During the ablation period, spatial snow distributions are mainly influenced by differences in snowmelt behaviour. On the Northern Hemisphere, on south-facing slopes, rates of snowmelt are generally enhanced compared to north-facing slopes due to the inclination of radiation. Also vegetation influences melting behaviour. Shading reduces snowmelt compared to direct sunlight. Enhanced emitted long wave radia- tion due to warm bare rocks or trees increases the melt rate (Garvelmann et al., 2013; Pohl et al., 2014).

\subsection{Modelling approaches}

There exist a plenty of model concepts to simulate the snow redistribution in mountainous areas, ranging from simple conceptual models to complex, physically based ones. The latter attempt to consider all energy fluxes and therefore show a huge data demand with respect to meteorological input. Usually this type requires high spatial resolution of the model domain. Alternatively, the conceptual models can also be easily applied for meso- and macro-scale basins, where the spatial resolution generally shows coarser grid spacing. This is the case for the introduced study where the entire basin of the river Inn was modelled (see Frey et al., 2014), and selective results of the Ötztal are presented.

Generally, there are several ways of coping with intensive snow accumulations in hydrological models, in particular (i) adapting the meteorological input data, (ii) the application of physically based models to solve the full energy balance and considering the wind-induced snow drift and (iii) conceptual models using topographic information for lateral snow transport. In the following some descriptions and references of the respective concepts are given.

A common approach is editing the meteorological input (Dettinger et al., 2004). For instance, many models use a constant yet adjustable lapse rate for interpolating temperature with elevation (Holzmann et al., 2010; Koboltschnig et al., 2008). Besides temperature, precipitation gradients are often adjusted to fit observed and modelled target variables (e.g. snow patterns or runoff) (Huss et al., 2009b; Schöber et al., 2014). Justification for doing so is the general lack of gauging stations in the summit regions (Daly et al., 1994, 2008) along with the high error of precipitation gauges (Rasmussen et al., 2011; Williams et al., 1998). An approach presented by Jackson (1994) defining a precipitation correction matrix was successfully applied in several studies (Farinotti et al., 2010; Huss et al., 2009a). Using a Doppler $\mathrm{X}$-band radar capable of a spatial resolution of $75 \mathrm{~m}$, Scipión et al. (2013) identified significant discrepancies between precipitation patterns in 300-600 $\mathrm{m}$ above ground and the snow accumulation at the end of the winter period in a small area of $1.5 \mathrm{~km}^{2}$ in the vicinity of Davos, Switzerland. They conclude that snowfall variability at the height of some hundreds of metres above ground is not the driving factor of snow accumulation variabilities at the scale of the radar's resolution. Consequently, the variability of the meteorological input cannot explain the variability of snow cover patterns.

Models trying to deal with snow accumulation and redistribution apart from input corrections may be classified into two major approaches. One is the consideration of processbased snow distribution patterns. Examples are SNOWPACK (Bartelt and Lehning, 2002) used in avalanche research or SnowTran3D (Liston et al., 2007; Liston and Sturm, 1998). 
The other approach is empirical. Models following the second approach use the fact that snow patterns resemble each other every year (Helfricht et al., 2012, 2014). Since our model is following the empirical approach, too, the presented paper concentrates on that approach.

Snow accumulation gradients determined by airborne lidar measurements (Helfricht et al., 2012) were used by Schöber et al. (2014) to improve hydrological modelling using the distributed energy balance model SES (Snow and Ice Melt; Asztalos, 2004). Lidar data, however, are relatively expensive to obtain. A common way of dealing with snow accumulations without the need for intensive field campaigns is using wind speed and direction to model lateral snow transport (e.g. Bernhardt et al., 2009, 2010; Shulski and Seeley, 2004; Winstral et al., 2002; Liston and Sturm, 1998). Wind information may be obtained by meteorological stations or by computed wind fields. Kirchner et al. (2014) concluded from Lidar measurements in combination with meteorological stations in a catchment in California, USA, that wind measurements from only one meteorological station are of too poor quality for a useful description of wind fields for snow transport. Due to the mentioned lack of meteorological stations in high elevations, the use of computer-generated wind fields seems appealing. This information has been successfully used to model snow redistributions in small scales of $30 \mathrm{~m}$ (Bernhardt et al., 2009, 2010, 2012). Those models using wind information have in common that they are computationally intensive as they require data in high spatial resolution (e.g. from 100 to thousands of square metres). Wind fields may also be generated by regional circulation models (RCMs). However, these wind fields have shown to be erroneous (Nikulin et al., 2011) and therefore are not useful for direct implementation in redistribution models. A combined approach using gravity and wind-induced snow transport was presented by Schöber et al. (2014), who used a distributed energy balance model with a resolution of $50 \times 50 \mathrm{~m}$. The SnowSlide model (Bernhardt and Schulz, 2010) applied to the Watzmann massif, Germany, only accounts for gravitationally induced snow transport.

The mentioned model approaches have in common that they operate on spatial scales of tens to hundreds of metres. However, due to some available databases for vegetation and meteorology (Haiden et al., 2011; Hiebl and Frei, 2015; Masson et al., 2003; Oubeidillah et al., 2014), many models operate on cell sizes of $1 \mathrm{~km}^{2}$ or more (e.g. Andersen et al., 2001; Henriksen et al., 2003; Mauser and Bach, 2009; Safeeq et al., 2014). While the main driving physical processes on the scale of these data sets might differ from the scale of the modelling approaches described above, the difficulties of snow accumulations also occur when models with grid cell sizes of $1 \times 1 \mathrm{~km}$ are applied to mountainous regions. Yet, to our knowledge, no model for redistributing snow on a $1 \times 1 \mathrm{~km}$ grid size exists. In this paper we present a simple approach to deal with snow in high mountainous regions and its application in the catchment of Ötztaler Ache in Tyrol, Austria. Since the model uses meteorological input from INCA (Integrated Nowcasting through Comprehensive Analysis; Haiden et al., 2011) that already account for meteorological corrections, we focus on snow redistribution rather than editing the input data. As already mentioned, the two main objectives in this respect are to achieve a better model efficiency regarding runoff and to avoid the existence of snow towers at high altitudes.

\section{Model description}

\subsection{Hydrological model COSERO}

COSERO (Continuous Semi-distributed Runoff) is a spatially distributed conceptual hydrological model which is similar to the HBV model (Bergström, 1976). In the presented paper it uses $1 \times 1 \mathrm{~km}$ grid cells. Originally developed for modelling discharge of the Austrian rivers Enns and Steyr (Nachtnebel et al., 1993), it has recently been used for different purposes like climate change studies (e.g. Kling et al., 2012, 2014b; Stanzel and Nachtnebel, 2010), investigating the role of evapotranspiration in high alpine regions (Herrnegger et al., 2012) and operational runoff forecasting (Stanzel et al., 2008). Potential evapotranspiration is calculated using the Thornthwaite method (Thornthwaite, 1948). Discharge due to rainfall and snow-/ice melt is estimated using the same non-linear function of soil moisture as the original HBV. In this study, the model is run using daily time steps. It is, however, capable of using hourly or monthly time steps. In the latter case, intra-monthly variations are considered for snow and interception processes as well as for soil moisture (Kling et al., 2014b). A schematic overview of the model is given in Fig. 1 and a detailed description of the model can be found in Kling et al. (2014a), where the model was applied to several catchments across Europe, Africa and Australia. However, in Kling et al. (2014a) snow parameters were not calibrated and therefore the snow module is not fully explained in detail in their paper. This will be done in the following. Equations (1)-(7) and Eq. (10) were taken from the original model by Stanzel and Nachtnebel (2010), all other methods were developed in the present study.

Numerous studies have shown that subgrid variability of snow depths can be described by a two-parameter log-normal distribution (e.g. Donald et al., 1995; Pomeroy et al., 1998). COSERO uses five snow classes per cell (i.e. the log-normal distribution is subdivided into five quantiles) to approximate this subgrid log-normal distribution under accumulation conditions (see Fig. 2b), i.e. snowfall is distributed log-normally into snow classes, where the sum of the snow water equivalent (SWE) of each class represents the mean conditions in the grid cell. This distribution can be interpreted as a statistical description of snow distribution processes taking place at the subgrid scale (Pomeroy et al., 1998). This method has the potential to indirectly consider the influence of curvature, 


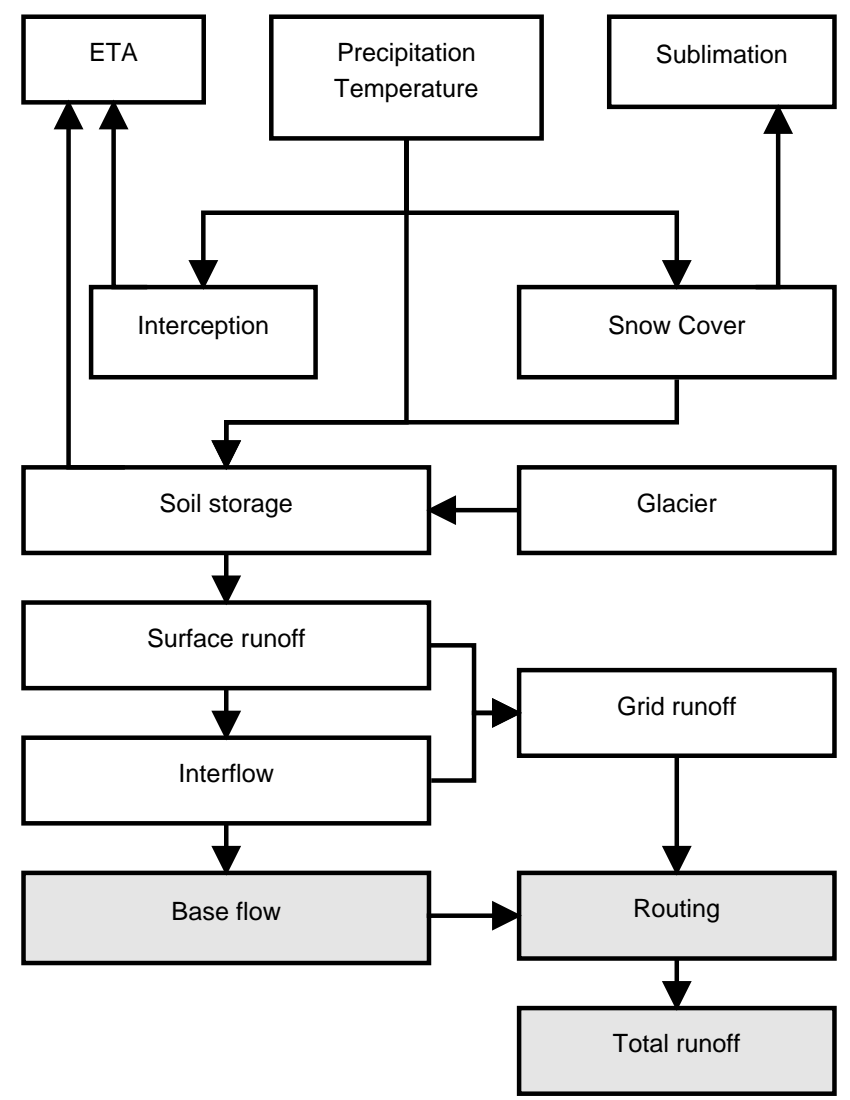

Figure 1. Flow chart of the conceptual model COSERO. White parts represent distributed processes, greyish parts are calculated on a subbasin scale. Snow transport is implemented in the snow cover module.

shelter, vegetation and elevation (Hiemstra et al., 2006). The properties of each class are treated unique as Eqs. (1)-(13) apply to every snow class separately. Consequently the lognormal distribution within a grid cell may be disturbed by the processes of melting, sublimation, refreezing and redistribution to other grid cells. Once fallen, snow redistribution between the snow classes within a single grid cell is not considered. A scheme of the composition of a snow class is illustrated in Fig. 2a. The snow water equivalent $\left(S_{\mathrm{SWE}_{t}}\right)$ of a given day $t$ per class is calculated by Eq. (1) where $P_{\mathrm{R}_{t}}$ and $P_{\mathrm{S}_{t}}$ are liquid and solid precipitation in millimetres, respectively, $M_{t}$ is snowmelt and $E_{\mathrm{S}_{t}}$ is sublimation of snow. All variables are given in millimetres of SWE.

$S_{\mathrm{SWE}_{t}}=S_{\mathrm{SWE}_{t-1}}+P_{\mathrm{R}_{t}}+P_{\mathrm{S}_{t}}-M_{t}-E_{\mathrm{S}_{t}}$

Snowmelt is calculated by a temperature index approach (see for example Hock, 2003). Equation (2) is used:

$M_{t}=\min \left(S_{\mathrm{SWE}_{t}} ; P_{R_{t}} \cdot \varepsilon \cdot T_{\mathrm{AIR}_{t}}+D_{f_{t}} \cdot T_{\mathrm{AIR}_{t}}\right)$,

where $M_{t}$ is snowmelt $(\mathrm{mm}), \varepsilon$ is the ratio of specific heat of water and melting energy, $T_{\mathrm{AIR}_{t}}$ is the (mean) daily air

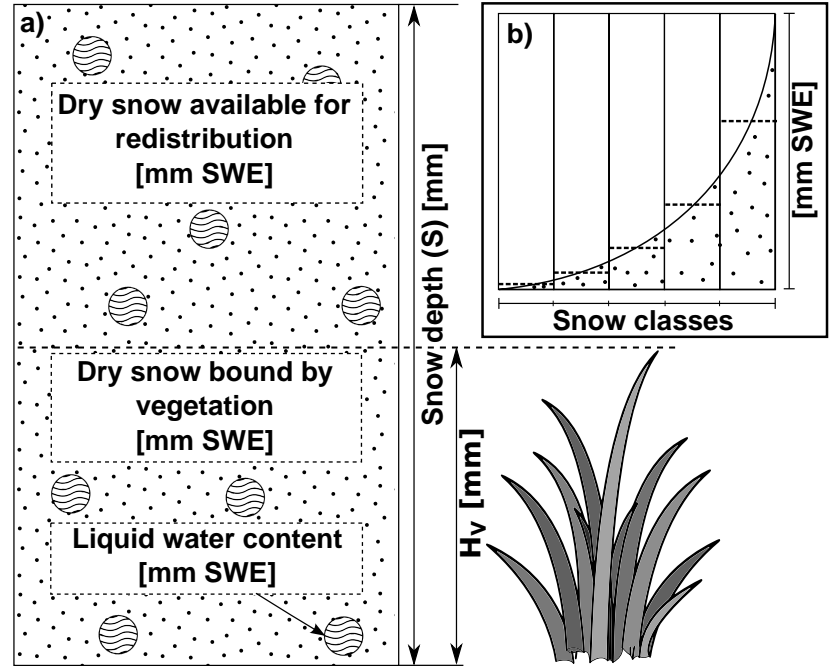

Figure 2. Schematic view of the snow cover in COSERO. (a) Composition of one snow class. Vegetation or surface roughness defines the threshold value $\left(H_{\mathrm{V}}\right)$ to hold back an amount of snow. (b) View of one grid cell including five snow classes each of which is composed in the way shown in (a). Snowfall is distributed log-normally throughout the classes (dashed lines in b). Note that snow depth $S$ is given in millimetres while all other parameters regarding snow are given in millimetres of SWE.

temperature $\left({ }^{\circ} \mathrm{C}\right)$ and $D_{\mathrm{f}_{t}}\left(\mathrm{~mm}^{\circ} \mathrm{C}^{-1}\right)$ is the snowmelt factor of a given day $t$ estimated by Eq. (3):

$D_{\mathrm{f}_{t}}=\left(-\cos \left(J \cdot \frac{2 \pi}{365}\right) \cdot \frac{D_{\mathrm{U}}-D_{\mathrm{L}}}{2}+\frac{D_{\mathrm{U}}-D_{\mathrm{L}}}{2}\right) \cdot M_{\mathrm{RED}_{t}}$

with

$M_{\mathrm{RED}_{t}}=\left\{\begin{array}{ll}D_{\mathrm{RED}}, & S_{\mathrm{fresh}} \geq S_{\mathrm{CRIT}} \\ M_{\mathrm{RED}_{t-1}}+\frac{\left(1-M_{\mathrm{RED}_{t-1}}\right)}{5}, & S_{\mathrm{fresh}}<S_{\mathrm{CRIT}}\end{array}\right.$,

where $J$ is the Julian day of the year $(-), D_{\mathrm{U}}$ and $D_{\mathrm{L}}$ are the upper and lower boundaries of $D_{\mathrm{f}}\left(\mathrm{mm}^{\circ} \mathrm{C}^{-1}\right)$, respectively, and $M_{\mathrm{RED}}(-)$ is a reduction factor to account for the higher albedo caused by freshly fallen snow calculated by Eq. (4). $S_{\text {CRIT }}(\mathrm{mm})$ is the critical snow depth of fresh snow necessary to increase the albedo, whereas $S_{\text {fresh }}$ is the actual depth of fresh snow $(\mathrm{mm})$ fallen within one time step. For fresh snow depth larger than $S_{\mathrm{CRIT}}, M_{\mathrm{RED}}$ is set to a reduced melting factor $D_{\text {RED }}(-)$.

Whether precipitation occurs in form of snow or rain is controlled by two parameters $T_{\mathrm{PS}}$ and $T_{\mathrm{PR}}$, defining the temperature range where snow and rain occur simultaneously. At and above temperature $T_{\mathrm{RP}}$ precipitation is pure liquid, at and below $T_{\mathrm{PS}}$ precipitation is pure solid. In between those two boundaries, the proportion of solid to liquid precipitation is estimated linearly.

For the estimation of snow sublimation, Eq. (5) is used, where $E_{\mathrm{SP}}(\mathrm{mm})$ refers to potential sublimation of snow, $E_{\mathrm{P}}$ 
(mm) is the potential evapotranspiration and $E_{\mathrm{R}}$ is a correction factor to reduce $E_{\mathrm{P}}$. Sublimation is considered only for snow classes actually covered by snow. Hence, if a grid cell is partly snow free (this can be the case if one subgrid class has no snow cover due to melting), sublimation is estimated for the snow-covered part only. For the uncovered classes, evapotranspiration according to the Thornthwaite method is applied.

$E_{\mathrm{SP}_{t}}=E_{\mathrm{P}_{t}} \cdot E_{\mathrm{R}}$

The snow cover in COSERO is treated as porous medium and therefore is able to store a certain amount of liquid water $\left(S_{1}, \mathrm{~m}^{3} \mathrm{~kg}^{-1}\right)$ in dependency of the snowpack density $(\rho)$ calculated using Eq. (6).

$S_{\mathrm{l}_{t}}=\left(S_{\mathrm{SWE}_{t}}-S_{\mathrm{l}_{t-1}}\right) \cdot\left(S_{\mathrm{MMAX}}-\left(\rho-\rho_{\mathrm{MAX}}\right) \cdot S_{\mathrm{l} \rho}\right)$

where $S_{\text {IMAX }}\left(\mathrm{m}^{3} \mathrm{~kg}^{-1}\right)$ is the maximum water holding capacity at the maximum snow density of the snowpack $\rho_{\text {MAX }}$ $\left(\mathrm{kg} \mathrm{m}^{-3}\right)$ and $S_{\mathrm{l} \rho}(-)$ describes the decrease of water holding capacity with increasing snow density $\rho$.

At negative air temperatures, retained meltwater has the ability to refreeze in the snowpack. The potential amount of refrozen water $\left(S_{\mathrm{R}}\right)$ is estimated by Eq. (7), where $R_{\mathrm{f}}$ is the refreezing factor $\left(\mathrm{mm}^{\circ} \mathrm{C}^{-1}\right)$. As long as there is enough liquid water in the snowpack, actual refreezing will be equal to potential refreezing.

$S_{\mathrm{R}}= \begin{cases}0, & T_{\mathrm{AIR}_{t}}>0 \\ R_{\mathrm{f}} \cdot\left(T_{\mathrm{AIR}_{t}} \cdot(-1)\right), & T_{\mathrm{AIR}_{t}} \leq 0\end{cases}$

Refrozen water is treated in the same way as snow. The amount of water leaving the snow cover then equals snowmelt minus retained water.

Snow density $\left(\rho_{t}\right)$ of each class is calculated using a sigmoid function shown in Eqs. (8) and (9) where $\rho_{\text {MAX }}$ and $\rho_{\text {MIN }}$ are the respective maximum and minimum values of $\rho, T_{\mathrm{AIR}}$ is the temperature of the air mass above the snow layer and $\rho_{\text {scale }}$ and $T_{\text {scale }}$ are scaling coefficients to calculate a transition temperature $\left(T_{\mathrm{tr}}\right)$ for the estimation of the snow density. Hereby, $\rho_{\text {scale }}$ adjusts the slope of the function, whereas $T_{\text {scale }}$ is responsible for a shift on the $x$ axis. These two parameters are set to fixed values of 1.2 and 1 , respectively. The solution of Eqs. (8) and (9) is illustrated in Fig. 3 for a range of typical air temperatures, where snowfall occurs. Already fallen snow can reach a higher density ( $\rho_{\text {OLD }}$ ) than fresh snow. Its density is calculated using a time settling constant ( $\rho_{\text {SET }}$, derived from Riley et al., 1973) until the maximum density is reached (Eq. 10).

$\rho_{t}=\left(\rho_{\mathrm{MAX}}-\rho_{\mathrm{MIN}}\right) \cdot\left(\frac{T_{+} t r}{\sqrt{1+\left(T_{\mathrm{tr}}\right)^{2}}}+1\right) \cdot 0.5+\rho_{\mathrm{MIN}}$

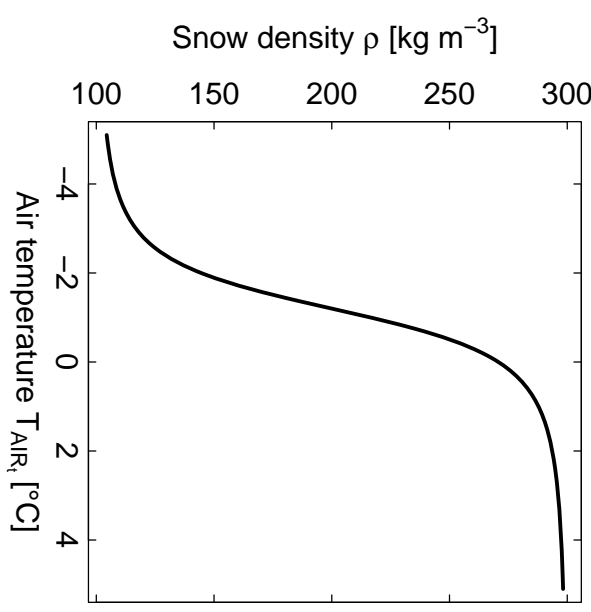

Figure 3. Estimation of the density of snow using Eqs. (8) and (9). Minimum and maximum densities of fresh snow are 100 and $300 \mathrm{~kg} \mathrm{~m}^{-3}$, respectively.

with

$T_{\mathrm{tr}}=\frac{T_{\mathrm{AIR}_{t}}}{\rho_{\mathrm{scale}}}+T_{\text {scale }}$

$\rho_{\mathrm{OLD}}=\frac{\rho_{\mathrm{SET}} \cdot\left(\frac{S_{\mathrm{SWE}_{t}}}{\rho_{\mathrm{OLD}}}+\frac{S_{t}}{2}\right)}{1+\frac{\rho_{\mathrm{SET}}}{2}}$.

The COSERO model considers both snow and glacier ice melt processes. Ice melt $\left(M_{\mathrm{ICE}}\right)$ is computed by means of a degree-day method (see Eq. 11) and uses separate parameter sets. Here, $D_{\text {ICE }}$ refers to the ice melt factor $\left(\mathrm{mm}^{\circ} \mathrm{C}^{-1}\right)$. A prerequisite of ice melt is the full depletion of the overlying snow cover. Spatial information of glaciers are taken from the Randolph Glacier Inventory version 3.2 (Arendt et al., 2012).

$M_{\mathrm{ICE}}=D_{\mathrm{ICE}} \cdot T_{\mathrm{AIR}}$

\subsection{Snow transport model}

Several authors reported that the slope angle has an important influence on snow depths (Bernhardt and Schulz, 2010; Kirchner et al., 2014; Schöber et al., 2014). The model redistributes snow only to grid cells providing the steepest slope (acceptor cell) in the direct neighbourhood of the raster cell it searches from (donor cell). Only downward transportation is considered. If more than one cell show the same (largest) difference in elevation, the amount of donated snow is distributed equally to the number of acceptor cells. The actual amount of snow being redistributed depends on the steepness of the slope, the age of the snow cover, considered by the density of snow, the type of land cover of the donor cell and the snow depth of the donor cell. The drier (less dense) the 


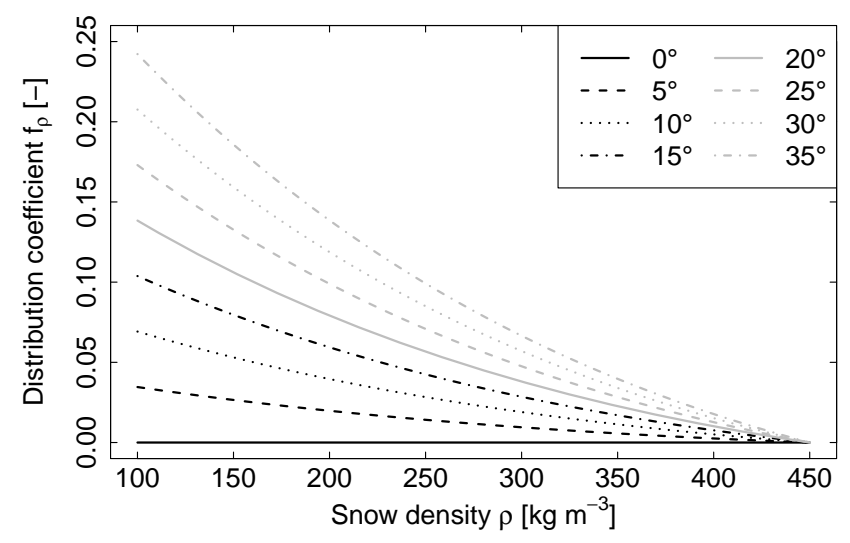

Figure 4. Shapes of the distribution coefficient in dependency of different slope angles and snow densities.

snowpack the higher the snow rate available for the redistribution routine $\left(f_{\rho}\right.$, Eq. 13). Thus, the defined maximum density of snow $\left(450 \mathrm{~kg} \mathrm{~m}^{-3}\right)$ determines the threshold for snow redistribution. The availability of snow for transport is determined by a vegetation-based threshold value $\left(H_{\mathrm{v}}\right)$ for each class of land cover. This value can also be interpreted as a roughness coefficient for areas where no or hardly any vegetation is present like in alpine and nival elevations. If the snow depth $(S, \mathrm{~mm})$ of a snow class of a raster cell exceeds $H_{\mathrm{v}}(\mathrm{mm})$, snow transport from that cell is activated and redistribution is calculated by solving Eqs. (12) and (13).

$S_{\mathrm{SWE}(A)}=\max \left(S_{\mathrm{D}}-H_{\mathrm{V}} ; 0\right) \cdot f_{\rho} \cdot \frac{1}{\sum A} \cdot C$

with

$f_{\rho}=\left(\frac{\left(\rho_{\mathrm{MAX}}-\rho_{\mathrm{D}}\right)}{\rho_{\mathrm{MAX}}} \cdot e^{\left(-\frac{\rho_{\mathrm{D}}}{\rho_{\mathrm{MAX}}}\right)}\right) \cdot \frac{\alpha}{90}$,

where $S_{\mathrm{SWE}(A)}$ is the amount of snow water equivalent that is redistributed from the donor cell $(D)$ to the available acceptor cell(s) $(A), \rho_{\mathrm{D}}$ is the density of snow in the donor cell, $\rho_{\mathrm{MAX}}$ is the possible maximum density of snow, $\alpha$ is the angle of the slope between the donor and acceptor cells in degree and $C$ is a correction coefficient that can be calibrated.

Figure 4 illustrates the shape of the distribution coefficient $f_{\mathrm{p}}$ as a function of different elevation gradients between the acceptor and donor cells and of the snow density. In acceptor cells redistributed snow is treated as fresh snow in the sense that it is distributed to the snow classes according to the lognormal distribution.

The model is organized in form of a loop starting at the highest grid cell (summit region) and ending at the lowest cell (outlet of the catchment). This ensures that snow cannot be redistributed into already processed grid cells. Snow will be transported downslope as long as the slope is steep enough to allow for transportation given that the density of snow is low enough (see Fig. 4). Consequently, less snow remains in the summit region whereas lower, rather flat grid
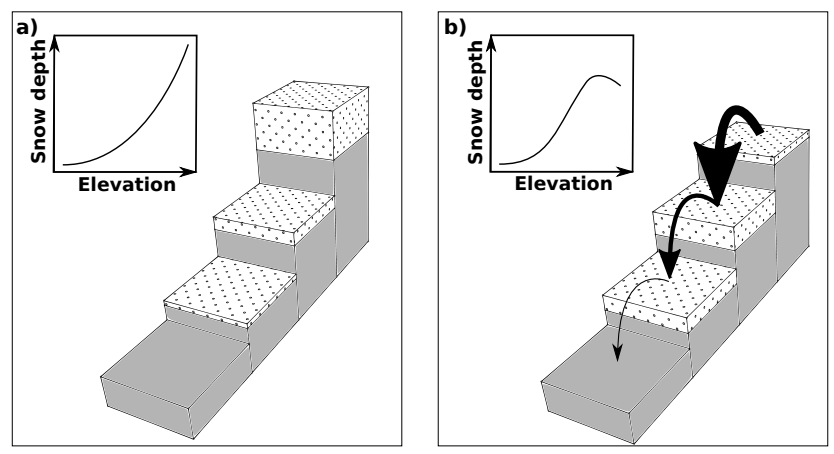

Figure 5. Conceptual snow accumulations in mountainous regions without (a) and with (b) lateral snow transport processes. Dotted blocks represent exaggerated snow accumulations.

cells show enhanced accumulation. Although snow depths in the summits are lower, the amount of snow-covered cells stay similar as some residual snow remains in all cells due to $H_{\mathrm{v}}$ parameterization.

The concept of the redistribution model is sketched in Fig. 5. Note that although snow depths in the highest cell are prevented by the model, the number of snow-covered cells remains the same.

\section{Case study in the catchment the Ötztaler Ache, Tyrol, Austria}

\subsection{Catchment description}

The catchment of Ötztaler Ache at the Huben gauge, situated in western Austria close to the Italian border, covers an area of $511 \mathrm{~km}^{2}$ and has an altitudinal range between $1185 \mathrm{~m}$ a.s.l. (above sea level) at the gauge at Huben and $3770 \mathrm{~m}$ a.s.l. at its highest peaks. Due to the use of a $1 \times 1 \mathrm{~km}$ gridded DEM (digital elevation model), the highest grid cell has a mean elevation of $3450 \mathrm{~m}$ a.s.l., whereas the lowest cell has an elevation of $1250 \mathrm{~m}$ a.s.l. (Fig. 6). About $30 \%$ of its area is covered by vegetation, mainly pastures and meadows. Glaciers cover about $19 \%$ leading to an annual ice melt contribution of about $25 \%$ of the total runoff at Huben, while $41 \%$ of the discharge has its origin in snowmelt (Weber et al., 2010). Table 1 gives an overview of the land cover.

In Fig. 6 the elevations of the Ötztal basin are described. Frequency distribution of slope angles derived from the $1 \times 1 \mathrm{~km}$ grid is shown (Fig. 6a). This frequency distribution exhibits the highest frequencies in the slope classes between 20 and $25^{\circ}$ for higher elevations. In lower elevated regions slope classes between 0 and $15^{\circ}$ dominate. However, also glacier-covered areas at the summits can have flat slopes. Note that the listed slopes are based on the steepest vertical gradients of the neighbouring elements. 
Table 1. Land use classes used in COSERO (derived from CORINE land cover data; EEA, 1995) and their proportion in the Ötztal. Snow holding capacities $H_{\mathrm{V}}$ for each type of land use are taken from Liston and Sturm (1998) and Prasad et al. (2001).

\begin{tabular}{lrr}
\hline Land use class & $\begin{array}{r}\text { Proportion } \\
(\%)\end{array}$ & $\begin{array}{r}\text { Snow } \\
\text { holding } \\
\text { capacity } \\
H_{\mathrm{v}}(\mathrm{mm})\end{array}$ \\
\hline Build-up areas & 1.2 & 100 \\
Pastures and meadows & 20.9 & 500 \\
Coniferous forests & 8.1 & 2500 \\
Sparsely vegetated areas & 20.9 & 300 \\
Bare rocks & 29.5 & 200 \\
Glaciers & 19.4 & 200 \\
\hline
\end{tabular}

\subsection{Input data}

Gridded meteorological data of precipitation and air temperature are required to run the model. These data are provided by the INCA data set (Haiden et al., 2011) with the same grid spacing as in the hydrological model, thus allowing a direct use in the model without the need for pre-processing. INCA data are available since 2003. The years 2003 and 2004 have been used as a warm-up period for the model. In the subsequent years no correction of meteorological data was done since INCA already accounts for elevation gradients regarding air temperature and precipitation. Six land use classes were derived from the most recent CORINE data set (CLC2006 version 17, see EEA, 1995). These classes and their areal fractions in the catchment of Ötztaler Ache are given in Table 1. It should be pointed out that neither radiation nor wind speed or wind direction data are necessary to run the model.

\subsection{Model calibration}

The hydrological model was calibrated for the period from 2005 to 2008 using Rosenbrock's automated optimization routine (Rosenbrock, 1960). Although the model is rich in parameters, the vast majority of them have been estimated a priori according to literature (Liston and Sturm, 1998; Prasad et al., 2001) and previous work on the model (Fuchs, 2005; Kling, 2006; Nachtnebel et al., 2009). In the snow model including snow redistribution, only six parameters have been calibrated: upper and lower boundaries of snowmelt factors $D_{\mathrm{U}}$ and $D_{\mathrm{L}}$, respectively, the threshold values that control the range where liquid and solid precipitation occur simultaneously $\left(T_{\mathrm{PR}}, T_{\mathrm{PS}}\right)$, the standard deviation of the log-normal distribution of snow depth in one grid cell $\left(N_{\mathrm{VAR}}\right)$ and the calibration parameter for snow redistribution $C$ (see Eq. 12). The limited number of optimization parameters reduces equifinality problems. For a more detailed description of equifinality issues see the supplements of this article. The target

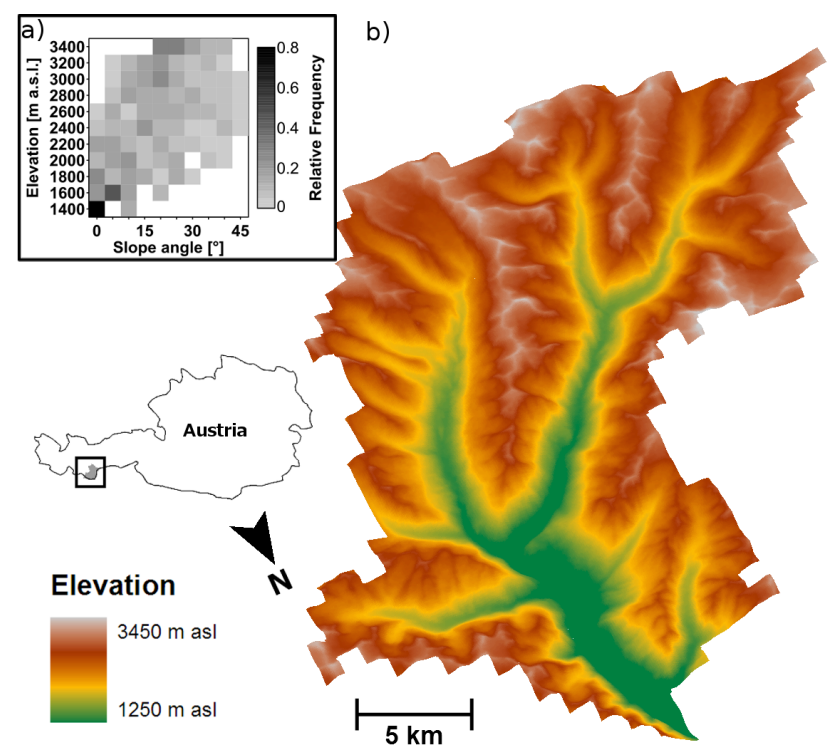

Figure 6. Elevation levels of the Ötztal using a $1 \times 1 \mathrm{~km}$ grid (b). Frequency distribution of slope angles derived from $1 \times 1 \mathrm{~km}$ grid is shown (a). Slopes in general are steeper in the summit regions than in the valleys. Note that instead of the average slope of a grid cell only steepest vertical gradients are plotted.

of the calibration was a good fit of runoff using the KlingGupta model efficiency (KGE; Gupta et al., 2009; Kling et al., 2012) as the objective function. The model was validated for the years 2009 and 2010. Both calibration and validation have been done with and without the snow transport module. In the following, model A refers to the model using snow transport, whereas model B stands for the standard model. Vegetation threshold values for snow detention were taken from previous studies (Liston and Sturm, 1998; Prasad et al., 2001). These are given in Table 1. Maximum snow density was assumed to be $450 \mathrm{~kg} \mathrm{~m}^{-3}$, which matches long-term snow measurements (Jonas et al., 2009; Schöber et al., 2014). Besides discharge in the validation period, snow cover data from MODIS (8-day maximum snow cover, version 5) satellite images (Hall et al., 2002) were also used to compare the performance of both models.

\section{Results}

\subsection{Discharge}

Figure 7 shows a comparison of total discharge using models A and B at the Huben gauge for the year 2006. Both models result in similar quality criteria in the calibration as well as in the validation period (see Table 2). Nevertheless, the model efficiency could be improved by 0.05 in the calibration period and by 0.02 in the validation period by accounting for lateral snow transport. Maximum differences in the mean daily discharges between the two models reach up to $2 \mathrm{~mm}$ per day 
Table 2. Comparison of performances of models A and B with respect to snow cover and runoff. For snow cover, the coefficient of determination $\left(R^{2}\right)$ was used, whereas the Kling-Gupta efficiency (KGE; Gupta et al., 2009) was used for runoff.

\begin{tabular}{cccccc}
\hline & \multicolumn{2}{c}{ Calibration } & & \multicolumn{2}{c}{ Validation } \\
\cline { 2 - 3 } \cline { 6 - 7 } & $\begin{array}{c}\text { Snow } \\
\text { cover } \\
\left(R^{2}\right)\end{array}$ & $\begin{array}{c}\text { Runoff } \\
(\text { KGE })\end{array}$ & & $\begin{array}{l}\text { Snow } \\
\text { cover } \\
\left(R^{2}\right)\end{array}$ & $\begin{array}{c}\text { Runoff } \\
(\text { KGE) }\end{array}$ \\
\hline Model A & 0.78 & 0.93 & & 0.74 & 0.92 \\
Model B & 0.70 & 0.88 & & 0.66 & 0.90 \\
\hline
\end{tabular}

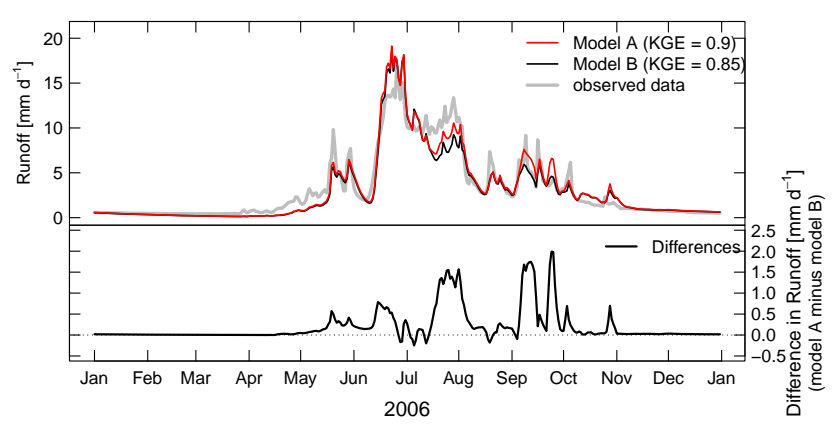

Figure 7. Specific runoff at the outlet at Huben is modelled with (model A) and without (model B) the snow redistribution routine.

$\left(12.1 \mathrm{~m}^{3} \mathrm{~s}^{-1}\right)$. This equals a relative difference of -9 , up to $44 \%$ of model $\mathrm{A}$ in respect to model $\mathrm{B}$. In total, model A generates a surplus of about $300 \mathrm{~mm}$ of discharge in 5 years compared to model B (Fig. 8). About two-thirds of the additional discharge originate in enhanced snowmelt, the rest occurs due to enhanced glacier melt.

\subsection{Spatially distributed snow cover data}

Figure 9 compares models A and B with MODIS snow depletion data. Both the accumulation period in winter and the ablation period in spring and summer are represented well by both models. Cold snowfall periods in summer generate sharp peaks in the depletion curve, which could be calculated by both model versions, where model A computed slightly smaller peaks during the snowmelt period (May-July). This leads to a moderate increase of the determination factor $R^{2}$ from 0.70 to 0.78 (calibration) and from 0.66 to 0.74 (validation).

\subsection{Inter-annual snow accumulation}

The main reason for developing a snow transport model was the prevention of "snow towers". Figure 10 presents model behaviour of models $\mathrm{A}$ and $\mathrm{B}$ with respect to the accumulation of snow in elevations above $2800 \mathrm{~m}$ a.s.l. Below that elevation none of the models indicate snow accumulation for more than 1 year and therefore snow accumulation in lower

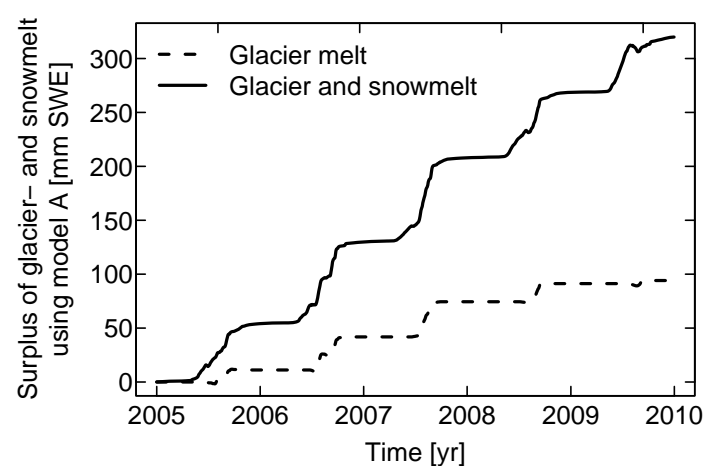

Figure 8. Accumulated differences (model A minus model B) in discharge at the Huben gauge.

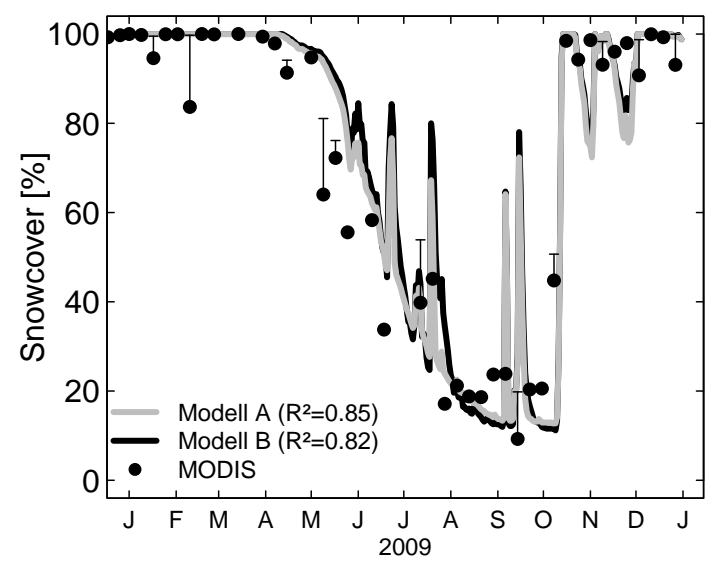

Figure 9. Snow cover in 2009 modelled by both models A and B compared with MODIS data. Error bars refer to uncertainties due to cloud coverage.

altitudes is no problem. By the end of 7 years of modelling, model B shows snow depths of approx. $2900 \mathrm{~mm}$ SWE in elevations above $3400 \mathrm{~m}$ a.s.1., whereas model A hardly shows any accumulation behaviour in these altitudes. Spatially distributed net loss and gain of snow for all raster cells within the period of 1 year in the watershed are presented in Fig. 11. It can be shown that net loss is evident in the zones of ridges and high elevations, where the maximum net gain is along the valley bottom.

\subsection{Parameter equifinality}

Since the model uses several parameters that need calibration, it suffers from equifinality issues. To investigate those issues, Monte Carlo simulations have been carried out varying the snow relevant parameters that cannot be estimated a priori. Since the aim of this paper is snow transport, the results of the Monte Carlo simulations can be found in the Supplement. 


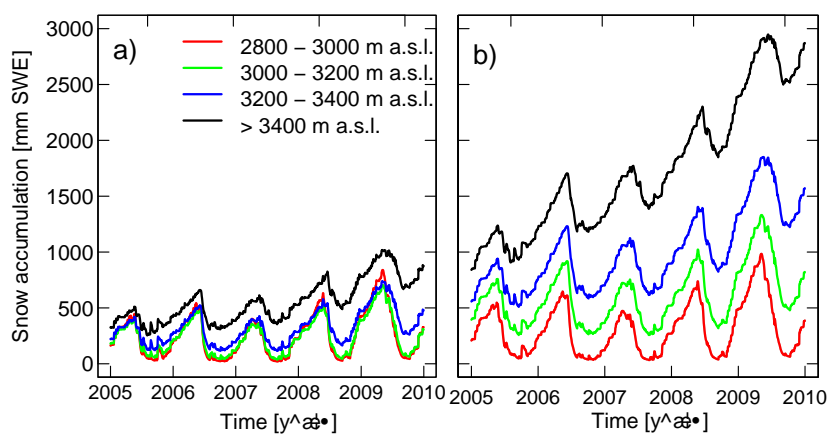

Figure 10. Behaviour of snow accumulation and melt of model A (a) and B (b) in the upper elevations. Note that model results are shown from 2005 to 2010 without the warm-up period for clarity reasons. Therefore, snow depth does not start at zero in the figure while it does at the beginning of the modelling.

\section{Discussion}

\subsection{Discharge}

In spring, at the beginning of the melting season, higher runoff is generated by the model accounting for lateral snow transport (model A) due to a larger amount of snow in lower altitudes (see Fig. 7). Later in the year enhanced glacier melt is mainly responsible for higher discharge rates. About $200 \mathrm{~mm}$ have their origin in enhanced snowmelt, while the remaining $100 \mathrm{~mm}$ originate in amplified melt of glaciers. Since glaciers cover about $19.4 \%$ of the catchment's area, $100 \mathrm{~mm}$ of additional mean basin runoff corresponds to an enhanced negative glacier mass balance of $-500 \mathrm{~mm}$. The reason for this is transport of snow in warmer altitudes and therefore earlier and more snow-free glacier surfaces producing higher discharge due to glacier melt (see Fig. 8) and explains the peak in July and August in runoff difference (see Fig. 7).

One has to be aware that the glacier model is very simple, since it treats glaciers as surfaces with infinite depths and static properties. However, besides an advanced algorithm that increases model complexity, a dynamic glacier model would require high spatial resolution information of both the glaciers' surfaces and the terrain (Farinotti et al., 2009). Since the intention of this paper was to develop a model operating at the $1 \times 1 \mathrm{~km}$ scale, this is not feasible.

\subsection{Spatially distributed snow cover data}

Figure 9 shows the snow depletion curve of the year 2009 based on MODIS data and the comparison of model runs A and B. Only little differences between models A and B can be identified. The reason for this is the vegetation threshold. Even if snow is being transported, a residual of snow remains in the donor cell, resulting in the cell marked as snow covered. Grid cells covering the summits only donate snow to their respective acceptor cells. However, a certain amount of

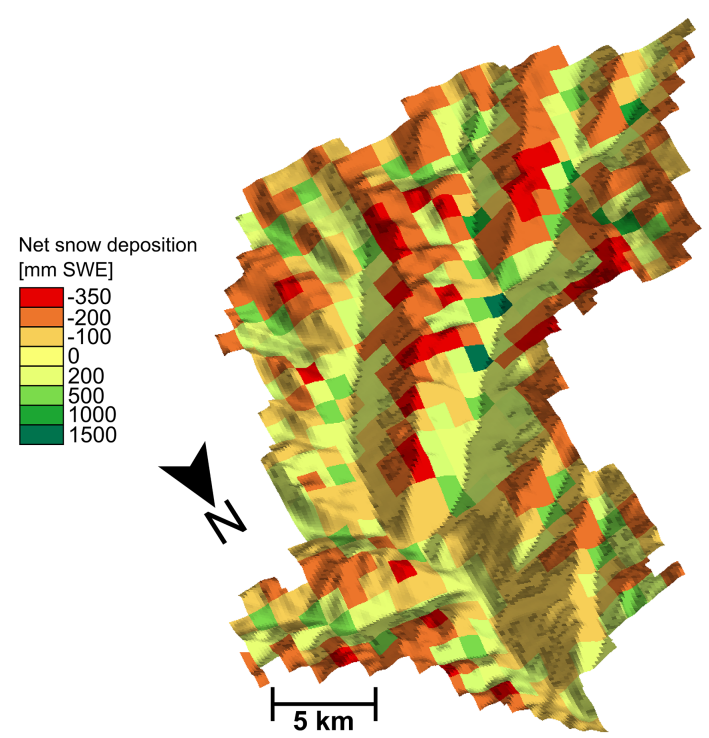

Figure 11. Net snow deposition in the catchment during the time period of 1 year. Negative values refer to a net loss and positive values to a net gain of snow. Note that, since only the net deposition of snow based on lateral transport is shown, values cannot be linked to snow depths at the end of the time period.

snow is held back according to the threshold due to vegetation and roughness of the surface. As indicated in Fig. 5 grid cells nested in the intermediate slope regions receive and donate snow at the same time. Thus, their snow depth changes little if comparing model A and model B. In flat valley regions, grid cells only receive snow, where relatively high air temperature values often allow for melting.

Satellite-based snow cover information by MODIS is binary and so is the model output for comparing these results. In a binary system, no difference can be distinguished between cells covered by much or little snow.

\subsection{Snow accumulation}

While using model B, the higher the elevation the more snow is accumulated. Conversely, model A shows less-pronounced and in some high altitudes even contrary behaviour (see Fig. 10). This is a result of the slope dependency on the distribution model. The amount of snow distributed to other grid cells is higher with increasing vertical distance to the downward grid cell (steeper slope). In general, as in the Ötztal, mountains are steeper in the summit regions than at the bottom (see Fig. 6). Consequently, in the summit regions snow will be preferentially eroded while it accumulates at the rather flat valleys where the vertical distances between the grid cells are less than at the peaks. This does reflect snow accumulations that can be observed in nature where summits might be nearly snow free in spring while flatter parts are still covered with snow. While the raster cells covering peak regions act as donators, only those cells located on slopes may 
receive and distribute snow at the same time (Fig. 11). Valley regions only receive snow. The resulting net loss and gain areas shown in Fig. 11 give some indication that the redistribution algorithm is plausible.

Although the snow accumulation behaviour of model A is more realistic than that of model B, snow accumulation can still be observed in the highest elevation zones (see Fig. 10). This is based on the parameterization of the snow holding capacity $H_{\mathrm{v}}$, where even bare ground is assigned a value of $200 \mathrm{~mm}$ (see Table 1). The influence of the highest elevation class ( $>3400 \mathrm{~m}$ a.s.l.) on both the hydrograph and snow-covered area however is very small, since this elevation level is represented by only $0.78 \%$ of the catchment's area. Consequently, the objective function during calibration using an automated optimization routine like Rosenbrock's routine does not differ much when underestimating the correction coefficient in these grid cells.

The smaller the portion of high altitude areas in a catchment compared to the total catchment area, the less important is snow redistribution for modelling runoff. The catchment of the river Inn, for instance, covers an area of about $10000 \mathrm{~km}^{2}$ yet only $733 \mathrm{~km}^{2}$ are located at elevations where intensive snow accumulations and mobilizations occur (above $2800 \mathrm{~m}$ a.s.1.). In the Ötztal Basin 204 out of $511 \mathrm{~km}^{2}$ are located higher than $2800 \mathrm{~m}$ a.s.l. If model B is applied to the catchment of the river Inn, in 5 years of modelling about $15 \mathrm{~mm} \mathrm{SWE}$ (with respect to the entire river basin) remain in the catchment due to snow accumulation processes instead of $300 \mathrm{~mm}$ in the Ötztal. These findings are based on an applied research project for the Austria's Verbund AG, where a hydrological model was applied for the assessment of the hydropower potential of the river Inn (see Frey and Holzmann, 2014; Frey et al., 2014)

\subsection{Transferability to other catchments}

The model provides results that have been found by other models and field observations, too. The largest snow accumulations occur at the elevation range between 2800 and $3000 \mathrm{~m}$ a.s.l. (Fig. 10). This was also found by lidar measurements carried out in the same catchment (Helfricht et al., 2012) as well as in several catchments in Switzerland (Grünewald et al., 2014). By applying a simple hydrological model that uses elevation bands instead of raster cells to a variety of other catchments in the Alps, Frey (2015) could identify this elevation range, too. Given that and the needs of the model (slope angles, snow density) for transporting snow, it produces valid results as long as a catchment features relatively steep slopes in the summit regions (which is the case in most catchments in the Alps). Obviously, the model needs calibration if it is transferred to another catchment.

\subsection{Parameter equifinality}

Like most hydrological models COSERO requires calibration of some parameters. This necessarily causes equifinality issues (Beven and Freer, 2001). The more adjustable parameters a model provides, the more important this problem may become (e.g. Gupta et al., 2008). On the other hand, some authors pointed out that more complex models may produce more feasible results if the parameters can be estimated within realistic boundaries (Gharari et al., 2013, 2014; Hrachowitz et al., 2014). Applying COSERO with the presented snow redistribution routine requires two additional parameters: the vegetation threshold $H_{\mathrm{v}}$ (estimated a priori) and the calibration parameter $C$ (see Eq. 12). Yet, accounting for snow redistribution allows the modeller to use $D_{\mathrm{U}}$ values within or close to the range proposed by Kling et al. (2006), while the standard version of the model leads to the best results if higher and therefore unrealistic $D_{\mathrm{U}}$ values are used (see the Supplement of this article).

\subsection{Scaling issues}

Notwithstanding that other geomorphological properties than slope angle influencing snow patterns are important on scales smaller than the grid size of COSERO (see Sect. 1.1), slope was selected as driving force for the model. One has to be aware that this is a simplification and under realistic conditions snow might not necessarily be transported only on the steepest route (Bernhardt and Schulz, 2010; Winstral et al., 2002). Also, the response of glaciers might change when finer spatial resolutions are applied. In a study at the Blaueisferner glacier, Germany, Bernhardt et al. (2010) found additional snow getting blown on glacier surfaces when they used a $30 \mathrm{~m}$ resolution. At the coarser resolution of $300 \mathrm{~m}$ this result could not be found, though. However, as indicated in the introduction, the $1 \times 1 \mathrm{~km}$ scale is often used when hydrological models are applied to medium or large catchments of hundreds or thousands of square metres, not only because of a variety of existing input data sets on that resolution but also for performance issues. The results of this study show that the model operating on that scale is able to reproduce the spatial snow distribution patterns in the catchment and prevent the model from accumulating snow over several years.

\section{Conclusions}

A model for redistribution of snow on a coarse $1 \times 1 \mathrm{~km}$ raster has been developed and tested in the catchment of Ötztaler Ache, Austria. While only little improvement of snow cover compared to MODIS data could be achieved, appearance of "snow towers" in high altitudes could be prevented. In terms of discharge at the outlet of the basin, both models show good results. However, the Kling-Gupta efficiency of model A could be improved by 0.05 in the calibration and by 0.02 in the validation period. With respect to the entire wa- 
tershed area, the model using snow redistribution generates about $200 \mathrm{~mm}$ of runoff more, originated from snowmelt in 5 years, than the model not using this process. This does not only affect the water balance of the catchment. Due to longer time periods where the overlaying snow cover on glacier surfaces is fully depleted, glacier melt is amplified by about $100 \mathrm{~mm}$ in 5 years. With respect to the glaciated area, this means that glaciers lose an additional $500 \mathrm{~mm}$ of their ice during that period. Since glaciers are represented in a very simple way in this model, these results need to be treated with caution. Nevertheless, glaciers play an important role in the water balance of alpine catchments and respond to snow redistribution also on the $1 \times 1 \mathrm{~km}$ scale.

The integration of a snow transport module promotes the notion that models work "right for the right reasons" and is an attempt to integrate more real process understanding into the model approach. Further work needs to be carried out with respect to validation of spatially distributed snow patterns. For this purpose, satellite images from Landsat might be of use providing a higher spatial resolution than MODIS.

Even though the vast majority of parameters were estimated a priori in this work, equifinality remains an issue. However, redistribution of snow requires only two additional parameters but allows for more realistic boundaries (see Kling et al., 2006) of the snowmelt factors (see Supplement of this article). However, more work needs to be carried out to account for that issue.

\section{The Supplement related to this article is available online at doi:10.5194/hess-19-4517-2015-supplement.}

Acknowledgements. The authors thank their colleagues for continuing support and discussion around the coffee breaks, especially to Matthias Bernhardt for his friendly reviewing and commenting on the manuscript. Special thanks to Herbert Formayer and David Leidinger of the institute of meteorology, BOKU, for supplying the INCA data. Many thanks to Daphné Freudiger and two further anonymous referees for their comments and valuable suggestions. This study was part of a research project in cooperation with Verbund AG.

Edited by: J. Seibert

\section{References}

Andersen, J., Refsgaard, J. C., and Jensen, K. H.: Distributed hydrological modelling of the Senegal River Basin model construction and validation, J. Hydrol., 247, 200-214, doi:10.1016/S0022-1694(01)00384-5, 2001.

Arendt, A., Bolch, T., Cogley, J. G., Gardner, A., Hagen, J.-O., Hock, R., Kaser, G., Pfeffer, W. T., Moholdt, G., Paul, F., Radić, V., Andreassen, L., Bajracharya, S., Barrand, N., Beedle, M., Berthier, E., Bhambri, R., Bliss, A., Brown, I., Burgess, D.,
Burgess, E., Cawkwell, F., Chinn, T., Copland, L., Davies, B., De Angelis, H., Dolgova, E., Filbert, K., Forester, R. R., Fountain, A., Frey, H., Giffen, B., Glasser, N., Gurney, S., Hagg, W., D., H., Haritashya, U. K., Hartmann, G., Helm, C., Herreid, S., Howat, I., Kapusti, G. G., Khromova, T., Kienholz, C., Köonig, M., Kohler, J., Kriegel, D., Kutuzov, S., Lavrentiev, I., Le Bris, R., Lund, J., Manley, W., Mayer, C., Miles, E., Li, X., Menounos, B., Mercer, A., Mölg, N., Mool, P., Nosenko, G., Negrete, A., Nuth, C., Pettersson, R., Racoviteanu, A., Ranzi, R., Rastner, P., Rau, F., Raup, B., Rich, J., Rott, H., Schneider, C., Seliverstov, Y., Sharp, M., Siguosson, O., Stokes, C., Wheate, R., Winsvold, S., Wolken, G., Wyatt, F., and Zheltyhina, N.: Randolph Glacier Inventory - A Dataset of Global Outliners: Version 3.2, Boulder, Colorado, USA, 2012.

Asztalos, J.: Ein Schnee- und Eisschmelzmodell für vergletscherte Einzugsgebiete, Thesis, Vienna University of Technology, Vienna, Austria, 2004.

Barros, A. P. and Lettenmaier, D. P.: Dynamic modeling of orographically induced precipitation, Rev. Geophys., 32, 265-284, doi:10.1029/94RG00625, 1994.

Bartelt, P. and Lehning, M.: A physical SNOATACK model for the Swiss avalanche warning Part I: numerical model, Cold Reg. Sci. Technol., 35, 123-145, doi:10.1016/S0165-232X(02)000745, 2002.

Bergström, S.: Development and application of a conceptual runoff model for Scandinavian catchments, SMHI Reports RHO No. 7, SMHI, Norrköping, 1976.

Bernhardt, M. and Schulz, K.: SnowSlide: A simple routine for calculating gravitational snow transport, Geophys. Res. Lett., 37, L11502, doi:10.1029/2010GL043086, 2010.

Bernhardt, M., Zängl, G., Liston, G. E., Strasser, U., and Mauser, W.: Using wind fields from a high-resolution atmospheric model for simulating snow dynamics in mountainous terrain, Hydrol. Process., 23, 1064-1075, doi:10.1002/hyp.7208, 2009.

Bernhardt, M., Liston, G. E., Strasser, U., Zängl, G., and Schulz, K.: High resolution modelling of snow transport in complex terrain using downscaled MM5 wind fields, The Cryosphere, 4, 99-113, doi:10.5194/tc-4-99-2010, 2010.

Bernhardt, M., Schulz, K., Liston, G. E., and Zängl, G.: The influence of lateral snow redistribution processes on snow melt and sublimation in alpine regions, J. Hydrol., 424-425, 196-206, doi:10.1016/j.jhydrol.2012.01.001, 2012.

Beven, K. and Freer, J.: Equifinality, data assimilation, and uncertainty estimation in mechanistic modelling of complex environmental systems using the GLUE methodology, J. Hydrol., 249, 11-29, doi:10.1016/S0022-1694(01)00421-8, 2001.

Bøggild, C. E., Knudby, C. J., Knudsen, M. B., and Starzer, W.: Snowmelt and runoff modelling of an Arctic hydrological basin in west Greenland, Hydrol. Process., 13, 1989-2002, doi:10.1002/(SICI)1099-1085(199909)13:12/13<1989::AIDHYP848>3.0.CO;2-Y, 1999.

Dadic, R., Mott, R., Lehning, M., and Burlando, P.: Parameterization for wind-induced preferential deposition of snow, Hydrol Process., 24, 1994-2006, doi:10.1002/hyp.7776, 2010 a.

Dadic, R., Mott, R., Lehning, M., and Burlando, P.: Wind influence on snow depth distribution and accumulation over glaciers, J. Geophys. Res.-Earth, 115, F01012, doi:10.1029/2009JF001261, 2010b. 
Daly, C., Neilson, R. P., and Phillips, D. L.: A StatisticalTopographic Model for Mapping Climatological Precipitation over Mountainous Terrain, J. Appl. Meteorol., 33, 140-158, doi:10.1175/1520-0450(1994)033<0140:ASTMFM>2.0.CO;2, 1994.

Daly, C., Halbleib, M., Smith, J. I., Gibson, W. P., Doggett, M. K., Taylor, G. H., Curtis, J., and Pasteris, P. P.: Physiographically sensitive mapping of climatological temperature and precipitation across the conterminous United States, Int. J. Climatol., 28, 2031-2064, doi:10.1002/joc.1688, 2008.

Dettinger, M., Redmond, K., and Cayan, D.: Winter Orographic Precipitation Ratios in the Sierra Nevada - Large-Scale Atmospheric Circulations and Hydrologic Consequences, J. Hydrometeorol., 5, 1102-1116, doi:10.1175/JHM-390.1, 2004.

Donald, J. R., Soulis, E. D., Kouwen, N., and Pietroniro, A.: A Land Cover-Based Snow Cover Representation for Distributed Hydrologic Models, Water Resour. Res., 31, 995-1009, doi:10.1029/94WR02973, 1995.

EEA: CORINE Land Cover Project, available at: http://www.eea. europa.eu/publications/COR0-landcover (last access: 12 December 2014), 1995.

Elder, K., Dozier, J., and Michaelsen, J.: Snow accumulation and distribution in an Alpine Watershed, Water Resour. Res., 27, 1541-1552, doi:10.1029/91WR00506, 1991.

Essery, R., Li, L., and Pomeroy, J.: A distributed model of blowing snow over complex terrain, Hydrol. Process., 13, 2423-2438, doi:10.1002/(SICI)1099-1085(199910)13:14/15<2423::AIDHYP853>3.0.CO;2-U, 1999.

Farinotti, D., Huss, M., Bauder, A., and Funk, M.: An estimate of the glacier ice volume in the Swiss Alps, Global Planet. Change, 68, 225-231, doi:10.1016/j.gloplacha.2009.05.004, 2009.

Farinotti, D., Magnusson, J., Huss, M., and Bauder, A.: Snow accumulation distribution inferred from time-lapse photography and simple modelling, Hydrol. Process., 24, 2087-2097, doi:10.1002/hyp.7629, 2010.

Frey, S.: Possible Impacts of Climate Change on the Water Balance with Special Emphasis on Runoff and Hydropower Potential, University of Natural Resources and Life Sciences, Vienna, PhD thesis, available at: http://permalink.obvsg.at/AC10777542, last access: 25 October 2015.

Frey, S. and Holzmann, H.: Berücksichtigung von Schneeverlagerungsprozessen bei der hydrologischen Modellierung alpiner Einzugsgebiete, in: Tri-Nationaler Workshop - Hydrologische Prozesse im Hochgebirge, Obergurgl, Austria, 2014.

Frey, S., Goler, R., Leidinger, D., Formayer, H., and Holzmann, H.: POWERCLIM - Final Report, Institute of Water Management, Hydrology and Hydraulic Engineering, University of Natural Resources and Life Sciences, Vienna, 2014.

Fuchs, M.: Auswirkungen von möglichen Klimaänderungen auf die Hydrologie verschiedener Regionen in Österreich, $\mathrm{PhD}$ thesis, University of Natural Resources and Life Sciences, Vienna, 2005.

Garvelmann, J., Pohl, S., and Weiler, M.: From observation to the quantification of snow processes with a time-lapse camera network, Hydrol. Earth Syst. Sci., 17, 1415-1429, doi:10.5194/hess-17-1415-2013, 2013.

Gharari, S., Hrachowitz, M., Fenicia, F., and Savenije, H. H. G.: An approach to identify time consistent model parameters: sub-period calibration, Hydrol. Earth Syst. Sci., 17, 149-161, doi:10.5194/hess-17-149-2013, 2013.

Gharari, S., Hrachowitz, M., Fenicia, F., Gao, H., and Savenije, H. H. G.: Using expert knowledge to increase realism in environmental system models can dramatically reduce the need for calibration, Hydrol. Earth Syst. Sci., 18, 4839-4859, doi:10.5194/hess-18-4839-2014, 2014.

Grünewald, T., Bühler, Y., and Lehning, M.: Elevation dependency of mountain snow depth, The Cryosphere, 8, 2381-2394, doi:10.5194/tc-8-2381-2014, 2014.

Gupta, H. V., Wagener, T., and Liu, Y.: Reconciling theory with observations: elements of a diagnostic approach to model evaluation, Hydrol. Process., 22, 3802-3813, doi:10.1002/hyp.6989, 2008.

Gupta, H. V., Kling, H., Yilmaz, K. K., and Martinez, G. F.: Decomposition of the mean squared error and NSE performance criteria: Implications for improving hydrological modelling, J. Hydrol., 377, 80-91, doi:10.1016/j.jhydrol.2009.08.003, 2009.

Haiden, T., Kann, A., Wittmann, C., Pistotnik, G., Bica, B., and Gruber, C.: The Integrated Nowcasting through Comprehensive Analysis (INCA) System and Its Validation over the Eastern Alpine Region, Weather Forecast., 26, 166-183, doi:10.1175/2010WAF2222451.1, 2011.

Hall, D. K., Riggs, G. A., Salomonson, V. V, DiGirolamo, N. E., and Bayr, K. J.: MODIS snow-cover products, Remote Sens. Environ., 83, 181-194, doi:10.1016/S0034-4257(02)00095-0, 2002.

Helfricht, K., Schöber, J., Seiser, B., Fischer, A., Stötter, J., and Kuhn, M.: Snow accumulation of a high alpine catchment derived from LiDAR measurements, Adv. Geosci., 32, 31-39, doi:10.5194/adgeo-32-31-2012, 2012.

Helfricht, K., Schöber, J., Schneider, K., Sailer, R., and Kuhn, M.: Interannual persistence of the seasonal snow cover in a glacierized catchment, J. Glaciol., 60, 889-904, doi:10.3189/2014JoG13J197, 2014.

Henriksen, H. J., Troldborg, L., Nyegaard, P., Sonnenborg, T. O., Refsgaard, J. C., and Madsen, B.: Methodology for construction, calibration and validation of a national hydrological model for Denmark, J. Hydrol., 280, 52-71, doi:10.1016/S00221694(03)00186-0, 2003.

Herrnegger, M., Nachtnebel, H.-P., and Haiden, T.: Evapotranspiration in high alpine catchments - an important part of the water balance!, Hydrol. Res., 43, 460-475, doi:10.2166/nh.2012.132, 2012.

Hiebl, J. and Frei, C.: Daily temperature grids for Austria since 1961 - concept, creation and applicability, Theor. Appl. Climatol., doi:10.1007/s00704-015-1411-4, in press, 2015.

Hiemstra, C. A., Liston, G. E., and Reiners, W. A.: Observing, modelling, and validating snow redistribution by wind in a Wyoming upper treeline landscape, Ecol. Modell., 197, 35-51, doi:10.1016/j.ecolmodel.2006.03.005, 2006.

Hock, R.: Temperature index melt modelling in mountain areas, J. Hydrol., 282, 104-115, doi:10.1016/S0022-1694(03)00257-9, 2003.

Holzmann, H., Lehmann, T., Formayer, H., and Haas, P.: Auswirkungen möglicher Klimaänderungen auf Hochwasser und Wasserhaushaltskomponenten ausgewählter Einzugsgebiete in Österreich, Österreich. Wasser Abfallwirt., 62, 7-14, doi:10.1007/s00506-009-0154-9, 2010. 
Hrachowitz, M., Fovet, O., Ruiz, L., Euser, T., Gharari, S., Nijzink, R., Freer, J., Savenije, H. H. G., and Gascuel-Odoux, C.: Process consistency in models: The importance of system signatures, expert knowledge, and process complexity, Water Resour. Res., 50, 7445-7469, doi:10.1002/2014WR015484, 2014.

Huss, M., Bauder, A., and Funk, M.: Homogenization of longterm mass-balance time series, Ann. Glaciol., 50, 198-206, doi:10.3189/172756409787769627, 2009a.

Huss, M., Farinotti, D., Bauder, A., and Funk, M.: Modelling runoff from highly glacierized drainage basins in a changing climate, Mitteilungen der Versuchsanstalt fur Wasserbau, Hydrol. Glaziol. Eidgenoss. Tech. Hochsch. Zurich, 22, 123-146, doi:10.1002/hyp.7055, 2009b.

Jackson, T. H. R.: A Spatially Distributed Snowmelt-Driven Hydrologic Model applied to the Upper Sheep Creek Watershed, PhD thesis, Utah State University, Logan, Utah, USA, 1994.

Jonas, T., Marty, C., and Magnusson, J.: Estimating the snow water equivalent from snow depth measurements in the Swiss Alps, J. Hydrol., 378, 161-167, doi:10.1016/j.jhydrol.2009.09.021, 2009.

Kirchner, P. B., Bales, R. C., Molotch, N. P., Flanagan, J., and Guo, $\mathrm{Q}$.: LiDAR measurement of seasonal snow accumulation along an elevation gradient in the southern Sierra Nevada, California, Hydrol. Earth Syst. Sci., 18, 4261-4275, doi:10.5194/hess-184261-2014, 2014.

Kling, H.: Spatio-Temporal Modelling of the Water Balance of Austria, PhD thesis, University of Natural Resources and Life Sciences, Vienna, 2006.

Kling, H., Fürst, J., and Nachtnebel, H. P.: Seasonal, spatially distributed modelling of accumulation and melting of snow for computing runoff in a long-term, large-basin water balance model, Hydrol. Process., 20, 2141-2156, doi:10.1002/hyp.6203, 2006.

Kling, H., Fuchs, M., and Paulin, M.: Runoff conditions in the upper Danube basin under an ensemble of climate change scenarios, J. Hydrol., 424-425, 264-277, doi:10.1016/j.jhydrol.2012.01.011, 2012.

Kling, H., Stanzel, P., and Preishuber, M.: Impact modelling of water resources development and climate scenarios on Zambezi River discharge, J. Hydrol. Reg. Stud., 1, 17-43, doi:10.1016/j.ejrh.2014.05.002, 2014a.

Kling, H., Stanzel, P., Fuchs, M., and Nachtnebel, H.-P.: Performance of the COSERO precipitation-runoff model under nonstationary conditions in basins with different climates, Hydrolog. Sci. J., 60, 1374-1393, doi:10.1080/02626667.2014.959956, 2014b.

Koboltschnig, G. R., Schöner, W., Zappa, M., Kroisleitner, C., and Holzmann, H.: Runoff modelling of the glacierized Alpine Upper Salzach basin (Austria): multi-criteria result validation, Hydrol. Process., 22, 3950-3964, doi:10.1002/hyp.7112, 2008.

Lehning, M. and Fierz, C.: Assessment of snow transport in avalanche terrain, Cold Reg. Sci. Technol., 51, 240-252, doi:10.1016/j.coldregions.2007.05.012, 2008.

Lehning, M., Bartelt, P., Brown, B., Fierz, C., and Satyawali, P.: A physical SNOWPACK model for the Swiss avalanche warning: part II, Snow microscrutcure, Cold Reg. Sci. Technol., 35, 147167, doi:10.1016/S0165-232X(02)00073-3, 2002.

Liston, G. E.: Representing Subgrid Snow Cover Heterogeneities in Regional and Global Models, J. Climate, 17, 1381-1397,
doi:10.1175/1520-0442(2004)017<1381:RSSCHI>2.0.CO;2, 2004.

Liston, G. G. and Sturm, M.: A snow-transport model for complex terrain, J. Glaciol., 44, 498-516, 1998.

Liston, G. E., Haehnel, R. B., Sturm, M., Hiemstra, C. A., Berezovskaya, S., and Tabler, R. D.: Simulating complex snow distributions in windy environments using SnowTran-3D, J. Glaciol., 53, 241-256, doi:10.3189/172756507782202865, 2007.

Masson, V., Champeaux, J.-L., Chauvin, F., Meriguet, C., and Lacaze, R.: A Global Database of Land Surface Parameters at 1-km Resolution in Meteorological and Climate Models, J. Climate, 16, 1261-1282, doi:10.1175/1520-0442-16.9.1261, 2003.

Mauser, W. and Bach, H.: PROMET - Large scale distributed hydrological modelling to study the impact of climate change on the water flows of mountain watersheds, J. Hydrol., 376, 362377, doi:10.1016/j.jhydrol.2009.07.046, 2009.

Melvold, K. and Skaugen, T.: Multiscale spatial variability of lidar-derived and modeled snow depth on Hardangervidda, Norway, Ann. Glaciol., 54, 273-281, doi:10.3189/2013AoG62A161, 2013.

Moore, R. J.: The PDM rainfall-runoff model, Hydrol. Earth Syst. Sci., 11, 483-499, doi:10.5194/hess-11-483-2007, 2007.

Nachtnebel, H. P., Baumung, S., and Lettl, W.: Abflussprognosemodell für das Einzugsgebiet der Enns und Steyer, Institute of Water Management, Hydrology and Hydraulic Engineering, University of Natural Resources and Life Sciences, Vienna, 1993.

Nachtnebel, H. P., Senoner, T., Stanzel, P., Kahl, B., Hernegger, M., Haberl, U., and Pfaffenwimmer, T.: Inflow prediction system for the Hydropower Plant Gabčíkovo, Part 3 - Hydrologic Modelling, Institute of Water Management, Hydrology and Hydraulic Engineering, University of Natural Resources and Life Sciences, Vienna, 2009.

Nikulin, G., Kjellström, E., Hansson, U., Strandberg, G., and Ullerstig, A.: Evaluation and future projections of temperature, precipitation and wind extremes over Europe in an ensemble of regional climate simulations, Tellus A, 63, 41-55, doi:10.1111/j.16000870.2010.00466.x, 2011.

Oubeidillah, A. A., Kao, S.-C., Ashfaq, M., Naz, B. S., and Tootle, G.: A large-scale, high-resolution hydrological model parameter data set for climate change impact assessment for the conterminous US, Hydrol. Earth Syst. Sci., 18, 67-84, doi:10.5194/hess18-67-2014, 2014.

Pohl, S., Garvelmann, J., Wawerla, J., and Weiler, M.: Potential of a low-cost sensor network to understand the spatial and temporal dynamics of a mountain snow cover, Water Resour. Res., 50, 2533-2550, doi:10.1002/2013WR014594, 2014.

Pomeroy, J. W., Gray, D. M., Shook, K. R., Toth, B., Essery, R. L. H., Pietroniro, A., and Hedstrom, N.: An evaluation of snow accumulation and ablation processes for land surface modelling, Hydrol. Process., 12, 2339-2367, doi:10.1002/(SICI)10991085(199812)12:15<2339::AID-HYP800>3.0.CO;2-L, 1998.

Pomeroy, J. W., Gray, D. M., Hedstrom, N. R., and Janowicz, J. R.: Prediction of seasonal snow accumulation in cold climate forests, Hydrol. Process., 16, 3543-3558, doi:10.1002/hyp.1228, 2002.

Prasad, R., Tarboton, D. G., Liston, G. E., Luce, C. H., and Seyfried, M. S.: Testing a blowing snow model against distributed snow measurements at Upper Sheep Creek, Idaho, United States of America, Water Resour. Res., 37, 1341-1356, doi:10.1029/2000WR900317, 2001. 
Rasmussen, R. M., Hallett, J., Purcell, R., Landolt, S. D., and Cole, J.: The hotplate precipitation gauge, J. Atmos. Ocean. Tech., 28, 148-164, doi:10.1175/2010JTECHA1375.1, 2011.

Riley, J., Israelsen, E., and Eggleston, K.: Some approaches to snowmelt prediction, Role Snowmelt Ice Hydrol, IAHS Publ., 107, 956-971, 1973.

Rosenbrock, H.: An automatic method for finding the greatest or least value of a function, Comput. J., 3, 175-184, doi:10.1093/comjnl/3.3.175, 1960.

Rutter, N., Essery, R., Pomeroy, J., Altimir, N., Andreadis, K., Baker, I., Barr, A., Bartlett, P., Boone, A., Deng, H., Douville, H., Dutra, E., Elder, K., Ellis, C., Feng, X., Gelfan, A., Goodbody, A., Gusev, Y., Gustafsson, D., Hellström, R., Hirabayashi, Y., Hirota, T., Jonas, T., Koren, V., Kuragina, A., Lettenmaier, D., Li, W. P., Luce, C., Martin, E., Nasonova, O., Pumpanen, J., Pyles, R. D., Samuelsson, P., Sandells, M., Schädler, G., Shmakin, A., Smirnova, T. G., Stähli, M., Stöckli, R., Strasser, U., Su, H., Suzuki, K., Takata, K., Tanaka, K., Thompson, E., Vesala, T., Viterbo, P., Wiltshire, A., Xia, K., Xue, Y., and Yamazaki, T.: Evaluation of forest snow processes models (SnowMIP2), J. Geophys. Res.-Atmos., 114, D06111, doi:10.1029/2008JD011063, 2009.

Safeeq, M., Mauger, G. S., Grant, G. E., Arismendi, I., Hamlet, A. F., and Lee, S.-Y.: Comparing Large-Scale Hydrological Model Predictions with Observed Streamflow in the Pacific Northwest: Effects of Climate and Groundwater, J. Hydrometeorol., 15, 2501-2521, doi:10.1175/JHM-D-13-0198.1, 2014.

Schaefli, B., Hingray, B., Niggli, M., and Musy, A.: A conceptual glacio-hydrological model for high mountainous catchments, Hydrol. Earth Syst. Sci., 9, 95-109, doi:10.5194/hess-9-95-2005, 2005.

Schöber, J., Schneider, K., Helfricht, K., Schattan, P., Achleitner, S., Schöberl, F., and Kirnbauer, R.: Snow cover characteristics in a glacierized catchment in the Tyrolean Alps - Improved spatially distributed modelling by usage of Lidar data, J. Hydrol., 519, 3492-3510, doi:10.1016/j.jhydrol.2013.12.054, 2014.

Scipión, D. E., Mott, R., Lehning, M., Schneebeli, M., and Berne, A.: Seasonal small-scale spatial variability in alpine snowfall and snow accumulation, Water Resour. Res., 49, 1446-1457, doi:10.1002/wrcr.20135, 2013.
Shulski, M. D. and Seeley, M. W.: Application of Snowfall and Wind Statistics to Snow Transport Modeling for Snowdrift Control in Minnesota, J. Appl. Meteorol., 43, 1711-1721, doi:10.1175/JAM2140.1, 2004.

Sovilla, B., McElwaine, J. N., Schaer, M., and Vallet, J.: Variation of deposition depth with slope angle in snow avalanches: Measurements from Vallée de la Sionne, J. Geophys. Res., 115, F02016, doi:10.1029/2009JF001390, 2010.

Stanzel, P. and Nachtnebel, H. P.: Mögliche Auswirkungen des Klimawandels auf den Wasserhaushalt und die Wasserkraftnutzung in Österreich, Österreich. Wasser Abfallwirt., 62, 180187, doi:10.1007/s00506-010-0234-x, 2010.

Stanzel, P., Kahl, B., Haberl, U., Herrnegger, M., and Nachtnebel, H. P.: Continuous hydrological modelling in the context of real time flood forecasting in alpine Danube tributary catchments, IOP Conf. Ser. Earth Environ. Sci., 4, 012005, doi:10.1088/17551307/4/1/012005, 2008.

Strasser, U., Bernhardt, M., Weber, M., Liston, G. E., and Mauser, W.: Is snow sublimation important in the alpine water balance?, The Cryosphere, 2, 53-66, doi:10.5194/tc-2-53-2008, 2008.

Thornthwaite, C. W.: An Approach toward a Rational Classification of Climate, Geogr. Rev., 38, 55-94, 1948.

Weber, M., Braun, L., Mauser, W., and Prasch, W.: Contribution of rain, snow- and icemelt in the upper Danube discharge today and in the future, Geogr. Fis. Din. Quat., 33, 221-230, 2010.

Williams, M. W., Bardsley, T., and Rikkers, M.: Overestimation of snow depth and inorganic nitrogen wetfall using NADP data, Niwot Ridge, Colorado, Atmos. Environ., 32, 3827-3833, doi:10.1016/S1352-2310(98)00009-0, 1998.

Winstral, A., Elder, K., and Davis, R. E.: Spatial Snow Modeling of Wind-Redistributed Snow Using Terrain-Based Parameters, J. Hydrometeorol., 3, 524-538, doi:10.1175/15257541(2002)003<0524:SSMOWR>2.0.CO;2, 2002.

Wood, E. F., Lettenmaier, D. P., and Zartarian, V. G.: A landsurface hydrology parameterization with subgrid variability for general circulation models, J. Geophys. Res., 97, 2717, doi:10.1029/91JD01786, 1992. 